\title{
Fryze reactive power of trams in effective stochastic recuperation processes
}

\author{
Oleh Bondar ${ }^{1}$, Mikola Kostin $^{1}$, Andrei Mukha ${ }^{1}$, Olha Sheikina ${ }^{1}$, and Svitlana Levytska ${ }^{2}$ \\ ${ }^{1}$ Dnipro National University of Railway Transport named after Academician V. Lazaryan, 2, Lazaryan Str., Dnipro, 49010, Ukraine \\ ${ }^{2}$ Prydneprovsk state Academy of Civil Engineering and Architecture, 24-a, Chernyshevskoho Str., Dnipro, 49600, Ukraine
}

\begin{abstract}
Urban electric transport system, particularly tram systems, is not a direct current system not only in traction mode but in regenerative modes as both voltage on a collector and regenerative current are stochastic abruptly variable processes. The above- mentioned facts determine availability of Fryze's reactive power in this system that flows from a railway substation to trams, leads to incidental losses of energy and significantly reduces its quality. So evaluation of power effectiveness of the system in electrical trams operation is impossible without determining the level of reactive power in this system. We have analytical expression of reactive power by Fryze. Numerical calculations for trams type T3D and T4D in regenerative braking modes are done. Probabilistic statistical data processing operation of reactive power expressions is done. It is determined that reactive power changes in the limit of $10 \ldots 100$ kilo-volt ampere reactive with mathematical expectation - 37,0 kilo-volt ampere reactive. Statistical allocation of random power values are different. Numerical calculations of incidental losses, energy of recuperation are done and they range supplementary $-20 \%$ from total losses. It is stated that coefficient of reactive power of system route of trams is exceeding permissible value 0,25 .
\end{abstract}

\section{Research Objective}

Municipal trams are the most widespread kind of electric rolling stock (ERS) of electric transport where there are often stops and starts and also regenerative braking (RB). The use of energy recovery in electric rolling stock is devoted to a significant number of scientific papers $[1,2]$ which contain both theoretical aspects and the results of experiments, including on the rolling stock of railways. The methodology of the experiments can be applied to urban electric transport, this aspect and sanctifies the presented robot.

The further usage of recuperative energy allows to reduce energy consumption by $30 \ldots 40 \%$ at tram movement. However, electric power effectiveness of the tram system service is to be estimated not only according to the volume and the usage state of recuperative energy but also taking into consideration such energy indicators as active power losses $\Delta P$ and reactive power factor $\operatorname{tg} \varphi$, that significantly depend on reactive power $Q_{F}$ as to well- known expressions:

$$
\Delta P=\frac{P^{2}+Q_{F}^{2}}{U^{2}} R,
$$

$$
\operatorname{tg} \varphi=\frac{Q_{F}}{P} .
$$

In contrast these indexes are not nearly investigated in spite of the fact that the processes of $\mathrm{RB}$ have been applied for a long time, almost from the beginning of introduction of track return system. Probably, it is connected with the thought that as the traction motors of trams are DC machines, so generated in the RB modes voltage and current are also constant so then the reactive power is missing. Actually, recuperated voltage $U(t)$, and current $I(t)$ are variable, even abruptly variable values that are typical for trams during the movement of ERS. In addition, they have stochastic nature (Fig. 1) due to technological probabilistic factors: weight and speed of wagons; rail profile; the mode of tram control (driver's qualification) etc. Therefore, the accuracy of estimation of electric power effectiveness of trams movement system in the RB modes is also defined by their reactive power level.

The object of the paper is to assess the impact of stochastic behavior of trams' traction voltages and currents on their Fryze's reactive power, energy indexes and technological losses of energy in regenerative modes.

* Corresponding author: sheikina.diit $@$ gmail.com 
a)
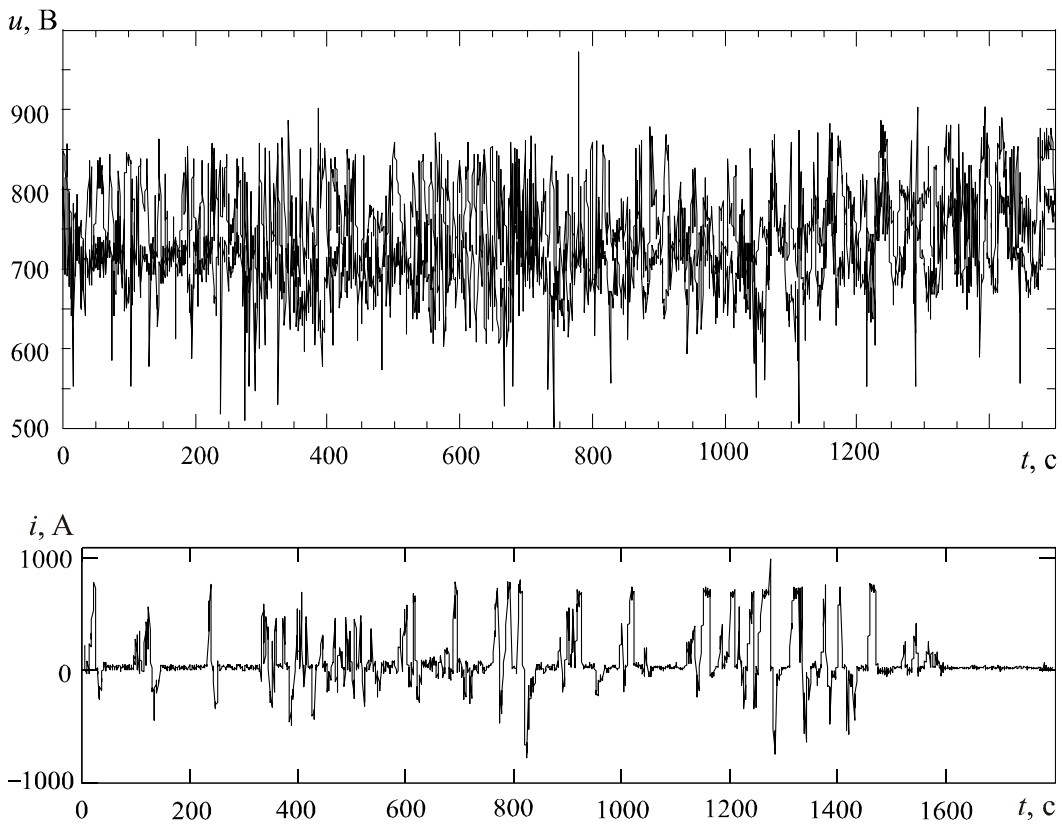

Fig. 1. Power tracing (a) and current (b) of tram in track regenerative mode: negative current values - recuperative current

\section{Theoretical Assumptions Determination of Powers.}

The ambiguity of concepts and formula determining reactive power in electric circuits with non-alternating voltage and current is well-known [3]. The main evidence of reactive power in the mentioned circuits which are specific also for track return system are: inequality of active and total powers of loading $(\mathrm{P} \neq \mathrm{S})$; distinction from zero angle of phase displacement between input voltage and current $\left(\varphi^{(k)}=0\right)$; the evidence of energy return from loading into source; variation in time of input instantaneous load resistance. Specified evidence corresponds most likely (in term of quantity) to the concepts and expressions of reactive power as to $\mathrm{K}$. Budeany and S. Fryze and also differential, integral and generalized reactive powers [3]. However, all scholars have the same idea as to the point of view in determining energy-efficiency as in fixed and so in transient state of system operation more correct and effective is the Fryze concept [4], according to which Fryze's reactive power is defined by well- known expression:

$$
Q_{F}=\sqrt{S^{2}-P^{2}} .
$$

Stochastic nature of generated $U(t), I(t)$ does not allow to use well-known in theoretical electrical engineering classical expressions for determining the reactive power, it is necessary to develop some specific methods that are performed particularly in [5]. Then in this paper we use the improved correlation method, the idea of which is given in [3] that is based on correlation theory of random stationary processes [6,7].

According to this theory, correlation function of voltage $K_{U}(\tau)$ and current $K_{I}(\tau)$ can be represented as mathematical expectations of scalar product of centered process $(U(t)$ or $I(t))$ and shifted to correlation window (time shift) $\tau$ copy of this process. Then, taking into account that unbiased estimation of mathematical expectation of stationary random process is its mean value for the time term of duration $T$ of member function can be written as:

$$
\begin{gathered}
K_{U}(\tau)=\frac{1}{T} \int_{0}^{T}\left[u(t)-m_{U}\right] \cdot\left[u(t+\tau)-m_{U}\right] d t, \\
K_{I}(\tau)=\frac{1}{T} \int_{0}^{T}\left[i(t)-m_{I}\right] \cdot\left[i(t+\tau)-m_{I}\right] d t,
\end{gathered}
$$

where $m_{U}, m_{I}$ are mathematical expectations of timeindependent processes as to the voltage and current.

In case of time shift $\tau=0$, after simple transformations and integration of relations (4) and (5) we have expressions of active values of voltage $U$ on a tram's current collector and its current $I$ :

$$
\begin{gathered}
U=\sqrt{D_{U}+m_{U}^{2}}, \\
I=\sqrt{D_{I}+m_{I}^{2}},
\end{gathered}
$$

where $D_{U}, D_{I}$ are dispersions as to the voltage and current that are equal to: $D_{U}=K_{U}(\tau=0)$; $D_{I}=K_{I}(\tau=0)$.

Taking account of (6) and (7), total power $S$ recuperated by a tram will be written by well-known formula as:

$$
S=U I=\sqrt{\left(D_{U}+m_{U}^{2}\right) \cdot\left(D_{I}+m_{I}^{2}\right)} .
$$

Active power of recuperation $P$ is defined using mathematical property of relative correlation function (in this case)of the voltage and current as mathematical expectations of scalar product of centered stochastic 
process of voltage $U(t)$ at shifted copy of centered process of current $I(t)$ :

$$
\begin{aligned}
& K_{U I}(\tau)=\frac{1}{T} \int_{0}^{T}\left[u(t)-m_{U}\right] \cdot\left[i(t+\tau)-m_{I}\right] d t= \\
& =\frac{1}{T} \int_{0}^{T} u(t) i(t+\tau) d t-\frac{m_{I}}{T} \int_{0}^{T} u(t) d t- \\
& -\frac{m_{U}}{T} \int_{0}^{T} i(t+\tau) d t+\frac{1}{T} \int_{0}^{T} m_{U} m_{I} d t .
\end{aligned}
$$

During time shift equal to zero $(\tau=0)$, after integration and in case $m_{U \mathrm{cp}}=m_{U}, m_{I \mathrm{cp}}=m_{l}$, we have:

$$
K_{U I}(\tau=0)=\frac{1}{T} \int_{0}^{T} u(t) i(t) d t-m_{I} m_{U}-m_{U} m_{I}+m_{U} m_{I},(10)
$$

where $m_{U \mathrm{cp}}, m_{\text {Icp }}$ are mean arithmetic values as to voltage and current for time interval $T$.

In (10) first term is an active power $P$ recuperated by a tram, then:

$$
P=m_{U} m_{I}+K_{U I}(\tau=0) .
$$

Then the required Fryze's reactive power is determined as:

$$
Q_{F}=\sqrt{\left[\left(D_{U}+m_{U}^{2}\right) \cdot\left(D_{I}+m_{I}^{2}\right)\right]-\left[m_{U} m_{I}+K_{U I}(\tau=0)\right]^{2}}
$$

The flowing of reactive power QF in the system "traction substation - tram" is related to incidental technological losses of electric energy recuperation. These losses are connected with defective restored energy and that is why should be the main effectiveness criterion of energy processes in the RB tram modes.

Nowadays there are no devices and methods for experimental observation of incidental losses and they can be determined only by calculation according to the expression:

$$
\Delta W_{\text {д }}=R \frac{Q_{F}^{2}}{U^{2}} \tau_{\mathrm{p}},
$$

where $R$ is active resistance of service area of electric traction network of tram power supply; $U$ is effective value of voltage on a tram's current collector in the regenerative mode; $\tau$ - recuperation time.

\section{Results and analysis of numerical calculations}

Using the obtained expressions and monitoring of the material from experimental record 30 voltage $U(t)$ and current $I(t)$ implementations (Fig. 2) that are carried out according to the theory [9], numerical calculations of reactive power of trams of $\mathrm{T} 3 \mathrm{D}$ and $\mathrm{T} 4 \mathrm{D}$ types in regenerative braking modes were done during their operation on the routes 11 and 17 of Dnipro city. Correlation functions of voltage on current collectors of trams and their regenerative current that are shown in Fig.3.

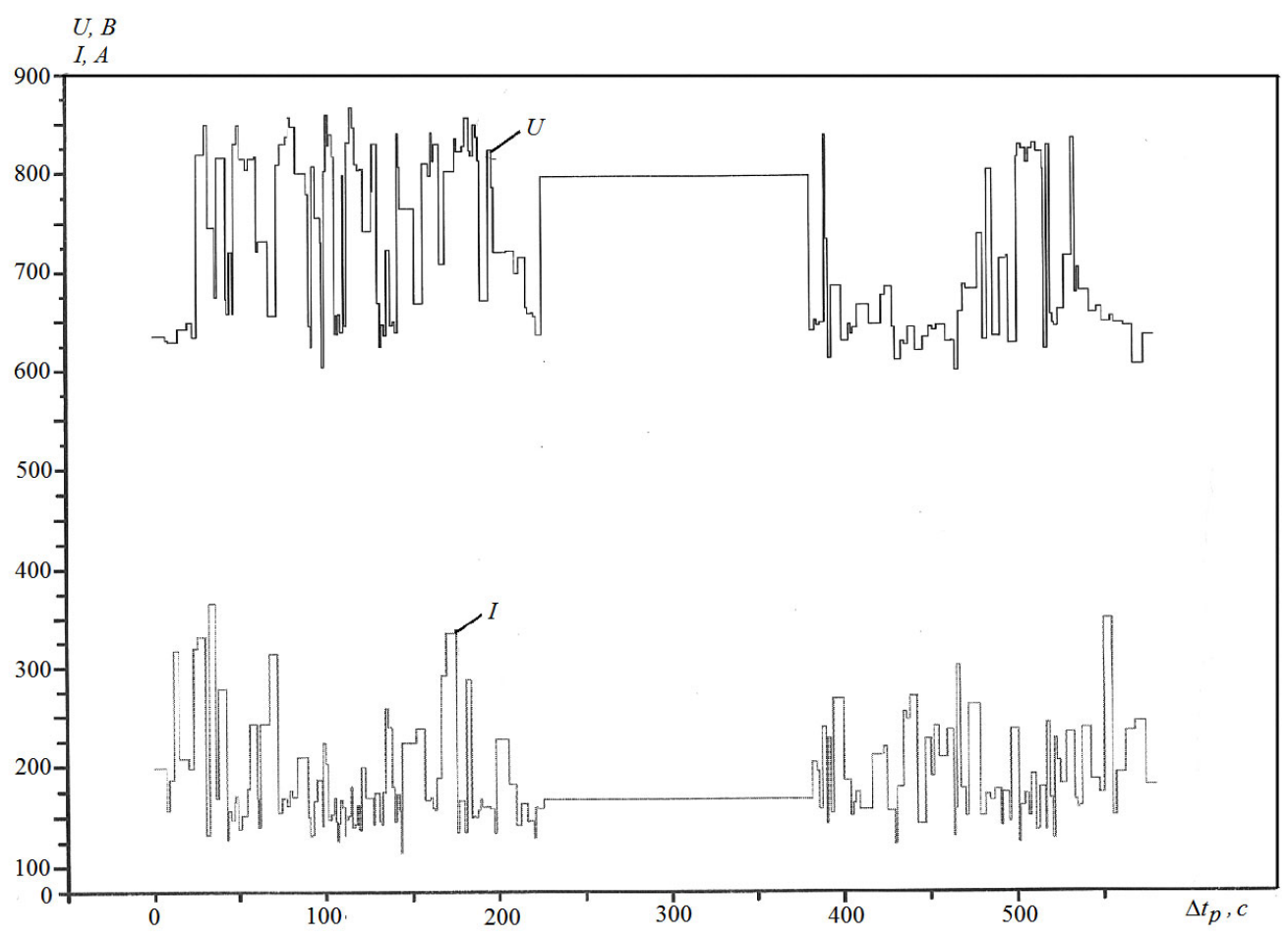

Fig. 2. Continuous voltage and current diagram of T4D tram in the recuperation mode 

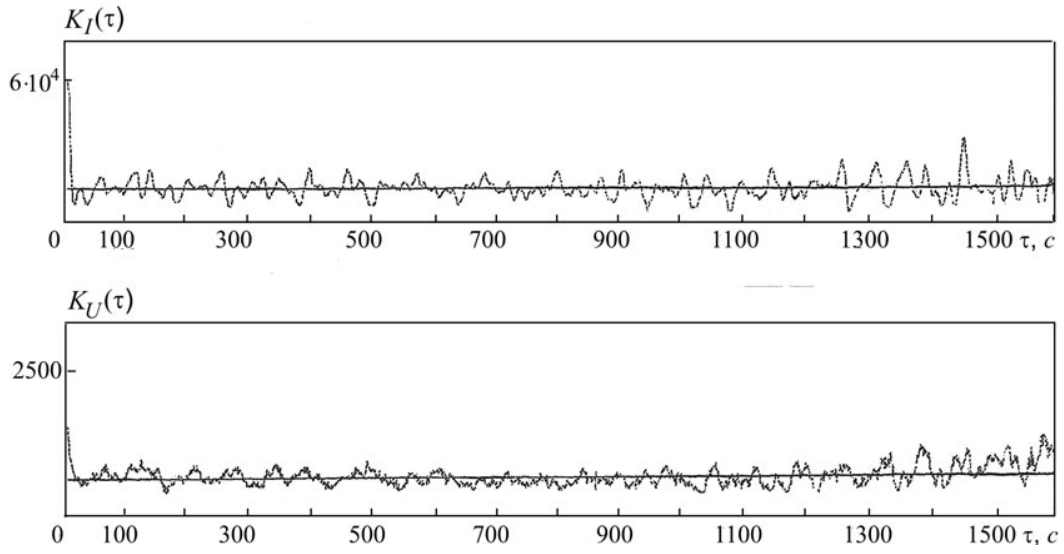

Fig. 3. Correlation functions of current and voltage of T4D tram in the recuperation mode

Abrupt random changes of voltage (Fig. 2, a) within $600 \ldots 900$ volt (at mathematical expectation 720 volt) and current (Fig. 2, b) at interval 100...350 ampere (at mathematical expectation 183.4A) lead to (as it is shown in Fig. 4) Fryze's reactive power $Q_{F}$ of trams is a random value that changes within $10 \ldots 100$ kilovolt-ampere reactive for one rail ride on the pointed route. In this way, mathematical expectations irrespective of a tram type and tram number equals to $\sim 37.0$ kilovolt-ampere reactive. Statistical distributions of the value $Q_{F}$ are different in relation to the routes: particularly, at the route 17 it is the law of Gauss with asymmetry coefficient 0.72 and excess 0.54 , on the route 11 - the value $Q_{F}$ follows asymmetric normal law with dispersive function [10].

The above-mentioned availability of reactive power leads to sufficiently high values of reactive power factor tg in the limits of $0.1 \ldots 0,486$ (at acceptable value 0.25 ) and incidental losses $\Delta W_{\text {д }}$ of restored energy (Fig. 5 ), that range to $20 \%$ of total losses $\Delta W$.

a)

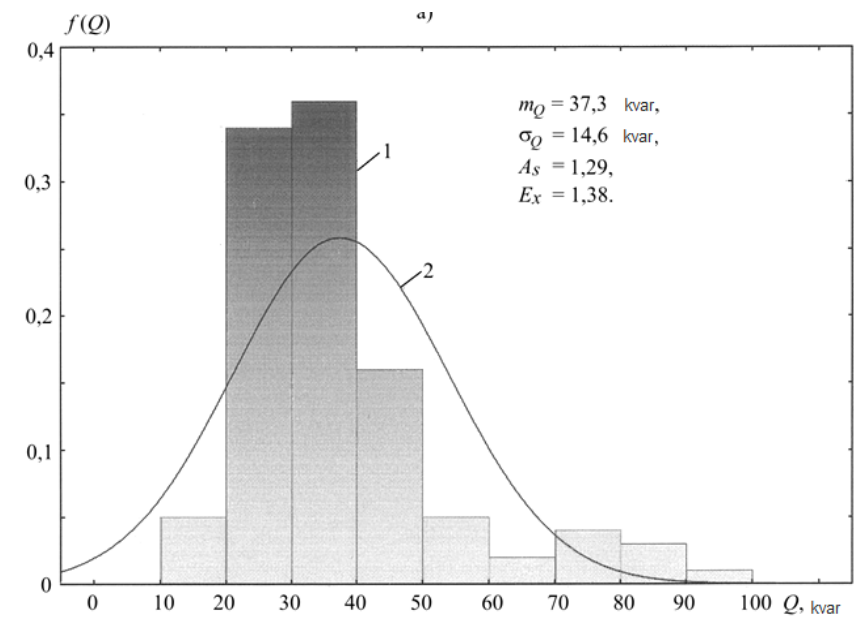

b)

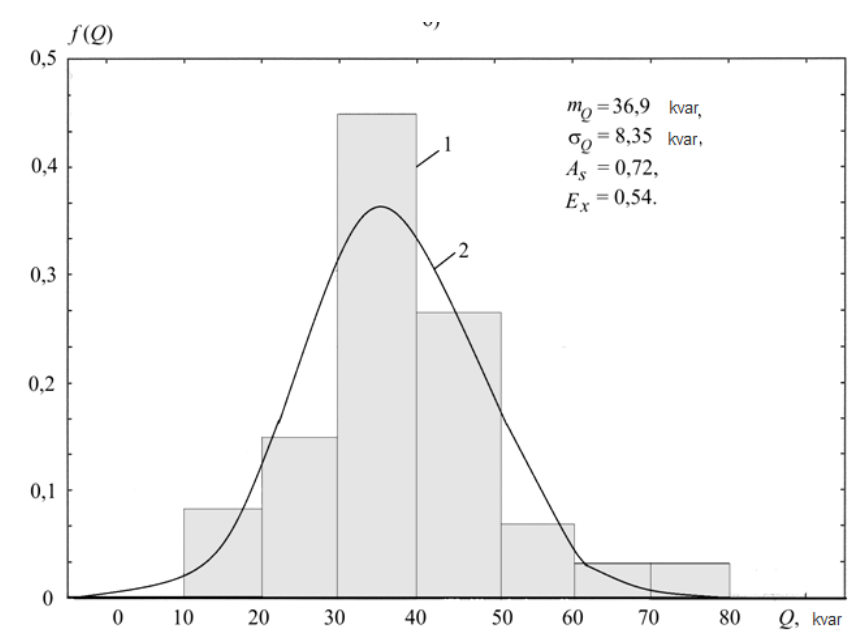

Fig. 4. Reactive power of T4D tram in the recuperation mode during the route № 11 (a) and route № 17 (b): statistical (1) and theoretical (2) distribution 


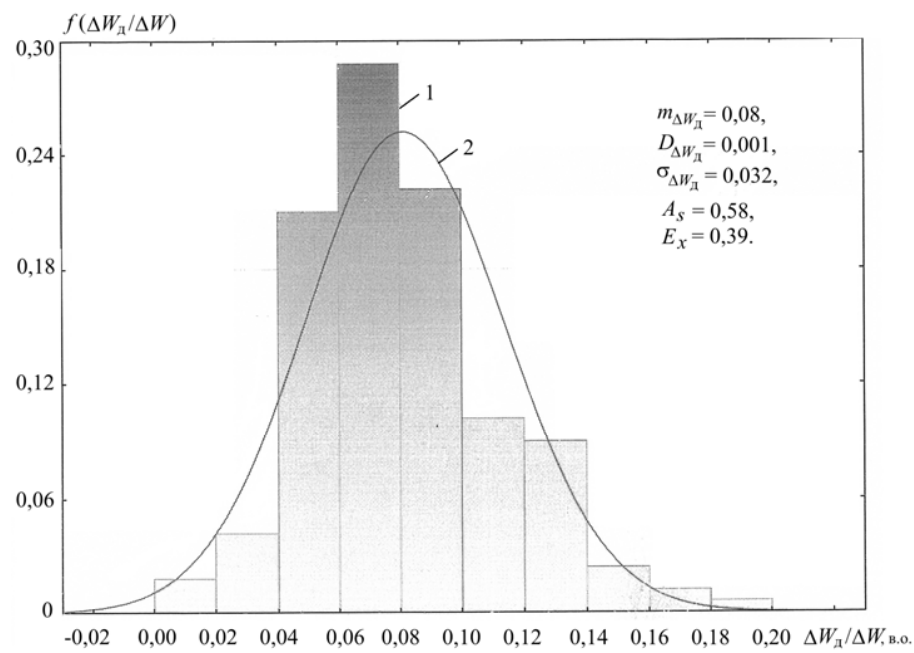

Fig. 5. Relative values of incidental losses of energy of recuperation in the system of electrically driven trams of type T3D and T4D: statistical (1) and theoretical (2) distribution

\section{Conclusions}

1. Abrupt random behavior of voltage change on a tram's current collector in regenerative mode leads to availability of Fryze's reactive power in the system.

2. In the phase of regenerative braking tram's voltage and current are stationary random process that gives the opportunity to define the reactive power and use correlation theory of random processes and particularly correlation-dispersion method.

3. Statistical distributions of reactive power are different according to the tram type and its route.

4. Availability of reactive power causes the occurring of incidental losses of restored energy in electric tram system and large (up to 0.486 ) coefficient values of reactive power $\operatorname{tg} \varphi$.

\section{References}

1. A. Mukha, M. Kostin, O. Bondar, A. Nikitenko, O. Kurylenko, Prerequsities of execution the experimental studies for definition of current state of using and accounting of the electrical rolling stock's regenerative energy on section of the "Pridniprovska" railway, Electrification of Transport, Dnipropetrovsk, Ukraine, № 13, pp. 5458, (2017) [in Ukrainian]

2. A. Nikitenko, M. Kostin, The method of the correlation and dispersion defining of the total power components in the electric transport devices, Science and Transport Progress. Bulletin of Dnipropetrovsk National University of Railway Transport, Dnipropetrovsk, Ukraine, vol. 1(44), pp. 64-75, (2013)

3. Czuchra W. Ocena energochłonności tramwajów z napędem asynchronicznym. 7tn International Conference «Modern Electric Transport in
Integrated XXI st Century Europe», Poland, Warsaw, - pp. 160-164, (2005)

4. Kostin M., Nikitenko A. Statistics and Probality Analysis of Voltage on the Pantograph of DC Electric Locomotive in the Recuperation Mode Przeglad Electrotechniczny. Warsaw, Poland. No 2a. - pp. 273-275, (2013)

5. Sajenko Ju. L. Reaktyvna potuzhnist' $v$ systemah elektropostachannja $z \quad$ nelinijnymy navantazhennjamy. Avtoref. dyss. na zdobuttja nauk. stupenja doktora tehn. nauk [Reactive power in power supply systems with nonlinear loads. Author's abstract. dis for obtaining sciences. doctor of technical sciences.]. L'viv, 36 p. (2003) [in Ukrainian]

6. Domnin I. F., Zhemerov G. G., Krilov D. S. [i dr.] Sovremennye teorii moshhnosti $i$ ih ispol'zovanie $v$ preobrazovatel'nyh sistemah jelektroniki Modern Power Theories and Their Use in Transforming Electronic Systems. Tehnichna elektrodynamika Technical electrodynamics, no 1, pp. 80-91 (2004) [in Russian]

7. Czarnecki L.: On some misinterpretations of the instantaneous reactive power $p-q$ theory. IEEE Trans. Power Electron, Vol. 19, Iss. 3, pp.828-836 (2004)

8. Herrera R. et al.: Present point of view about the instantaneous reactive power theory. IET Power Electron., Vol. 2, Iss. 5, pp. 484-495 (2009)

9. Fryze S. Wirk-, build- und scheinleistung in elektrischen stromkreisen min nicht sinsformigen verfaf von strom und spanning / S. Fryze // ETZ, Germany, No 25, pp. 596-599; No 26, pp. 625-627; No 29, pp. 700-702 (1932)

10. Kostin M. O., Petrov A. V. Metody vyznachennja skladovyh povnoi' potuzhnosti $v$ systemah elektrychnoi' tjagy [Methods of definition of components of total power in systems of electric 
propulsion]. Tehnichna elektrodynamika

Technical electrodynamics, no 3, pp. 53-59 (2011) [in Ukrainian]

11. Pugachev V.S. Teoriya sluchaynykh funktsiy $i$ eye primeneniye $k$ zadacham avtomaticheskogo upravleniya [The theory of the random functions and its using in the problems of the self-operated control systems]. Moscow : Gostekhizdat Publ., 659 p (1957) [in Russian]
12. Kostin N. A. Nekanonicheskoye spektralnoye razlozheniye sluchaynykh funktsiy tyagovykh napryazheniya $i$ toka $v$ sistemakh elektricheskogo transporta [Noncanonical spectral decomposition of random functions of traction voltage and current in electric transport systems.]. Elektrotekhnika i Elektromekhanika - Electrical engineering and electromechanics, no. 1, pp. 68-71 (2015) [in Russian] 